\title{
Semantic Rationing Between breadth and limitation
}

\author{
L. Furqan Muhammad Azeez, Department of Arabic Language - College of Basic Education, Al-Muthanna \\ University, furqanmohammed451@gmail.com
}

\begin{abstract}
Wideness and specification are two words that are called to judge its context, either by widening; Being not specific to a specific domain or specifically, to restrict it to a fully-related affair, its breadth was allocated to the intended delivery, taking into account the need in the language. One of the technologies has a broad meaning in its ruling on the general and common, including what is specified in a presumption stating a restriction or an allocation of the broad meaning; The verbal indication of amplitude differs from it in the definition, as the semantic widening does not make the text semantic and messy of understanding, but the text is a definite source, a determinant of the future, and a determinant of meaning, but the definition of meaning does not stop the group of interpretations chasing it.

The widening of the significance and its identification are among the goals that are used to communicate the intended, taking into account the necessity of the situation, and the officer who surrounds the significance is codified according to the context and the choice of the signifier's form of expressing the meaning is broad or specific, and these are among the characteristics that characterize the Qur'anic language and are largely related to the Qur'anic context; Some of the technologies achieve a broad meaning in its ruling on the general and common, and some of them are presented specifically with a presumption stating a restriction or an allocation of the broad meaning. The verbal indication of amplitude differs from it in the limitation, as there are factors such as the condition and the attribute ... that lead in turn to restriction and allocation.
\end{abstract}

Keywords: breadth , limitation, Semantic

Received: 07.12.2020 $\quad$ Accepted: 11.01.2021 $\quad$ Published: 03.02.2021

The following is a statement for each of them:

1- Amplitude:

When the people of the language are accomplished by mentioning ((the thing in his name is not associated with an adjective, nor a condition, nor a time, nor a number, nor something similar to that)), and this is about: ((That the person who says: (Zaid is lait)), this is only He likened it to the Leth in his courage)) The grammarians defined it as: ((All that is commented at the beginning of the case on the Shiites in its meaning, that is: ((What indicates one and not one $))$ )) And it is among the interpreters ((It does not require thumbs and rumors)) And among fundamentalists, it is ((a term for negligence in the context of evidence))) and also is ((what is indicated)

On a common meaning in his sex)) As for the rhetoric, ((he is vague and does not stand for meaning)), and also it is all that is common in his gender, and his rule is proven if it is limited in the sentence to mention the two parts of it ascribed and assigned to him from He mentioned to those related to them that is, the effects, dependencies, status, discrimination, and other related things are considered restrictions and their negation from the word makes it absolute.

Hence, the breadth of meaning is of two types:

-Individual: It is a term that indicates what is common in its gender, common between several types, and is achieved in:

A- Negligence: It is ((no more than two things and more, and what I want from one of the sexes is not specific)) and is used for many reasons, including:

Ignore:

To the Almighty saying: "And those who disbelieve said, Do we show you a man who tells you if you tear up all of you who are torn, that you have a disbelief in the form of a new (disbelief)?

Non-determination:

And he says: paz said to Joseph and his brother loved to our father and we League of the Father in manifest error 0 Slay Yusuf or cast ashore, without prejudice to you face your father and you will be after him a folk Salehing has received the word (the land) nobody without the appointment of any land Means. 
- Abundance towards the Almighty saying: p And we cut them on the ground as a nation from whom the righteous and those without them are (i.e. many nations in many countries of the earth

- reduction: and it says: p God promised believers and believers are Gardens underneath which rivers flow, and pleasant dwellings in the Gardens of Eden, and the pleasure of Allah the biggest is to win Alazim 0 , came the word (Radwan) nonperson ((and the presumption of being of God with Being greater than all that is in the Gardens of Aden from Naim is evidence that what is meant is: and a little contentment from God that empties him of the people of the Gardens of Aden is greater for them and greater than all the blessings in them)) .

Including the saying of al-Mutanabbi, praising Saif al-Dawla:

Somewhat stingy expels the Romans from them, and someday it dispels poverty and poverty.

He denied the word "horse" and denied the word "generosity", and he wanted a few horses and a small amount of generosity.

Glorification:

One of his examples is what was mentioned in the Almighty's saying, "Those of you who are guided by their Lord, and those who are the peasant," so denying the word "Huda" in the Qur'anic text indicates that it is absolute. In order to suit the degree of the successful people mentioned in the verse, it is only attained by the one who received the absolute guidance. The guidance in the verse is a vague rumor that is applicable to any type of guidance without specifying a specific type. He has benefited from glorification and perfection

- Absolute and not limited

One of his examples is the one who created the heavens and the earth and what is between them in six days, and then he leveled the throne, the Most Gracious, and he was asked of him as an expert. He wanted to say (so he asked an expert) that is, he asked about an expert who was compassionate ((ie, a horse who had sought refuge and called him to have mercy on him, and his supplication was answered to him, so the word was a denial of the will to be fired by an expert and more of the experienced experts on an experience)) .

B- Name of gender:

It is commented on something and on everything similar to it. The name of the collective sex and the name of the individual sex are divided into two types. Examples include what is mentioned in the Almighty saying: $\mathrm{p} 0$ you who believe, fulfill the contracts and the contracts here are a gender name that includes the written and written contracts.

C- Time of action:

That widening and specifying the concept of a thumb and a statement of a thumb, and that the verbs are words and symbols on the meanings and that the properties of meanings are clear and thumb; The extent and specification include the verbs in terms of (time), then the time - which the formula of the verb indicates - as it was believed - is a limit to the occurrence of the verb. For the verb, the context context interferes in determining the type of time to which the verb goes into. There is a sign of a morphological time, and a sign of a contextual time. Time is a function in the context that does not relate to a specific morphological form, but rather chooses the formula for which the clues that help in downloading it have the meaning of the specific time intended from the context))

Examples include what was mentioned in the verse of God Almighty: j And divorced women lie in wait for themselves three readings .

We find that the present tense (lying in wait) gives the indication of an unlimited time-expanding order; And by context context, and its indication of commissioning from the highest to the lowest, the breadth and the permissibility of leprosy have absolutely benefited the divorced women who divorced, and the news about the lying in the act came to increase the affirmation of the matter, and drew attention to it

The second: the syntax: is all that is mentioned from the two sentences restricted to the two pillars of the chain of transmission.

The sentences are either nominal or actual if they are mentioned without being related to the condition, the adjective, the distinction and the object in it ... etc. Their significance is absolute, and this can be achieved in the omission from the syntax, whether the deletion is a word or a sentence or an indication as follows:

1- Delete the word: and from it: and delete the object

One of his examples in the Almighty's saying, "The Lord will give you your Lord, and you will be satisfied." The contentment of the Messenger (may God's prayers and peace be upon him and his family) is absolute by deleting the sick thing in it and the act of giving. It was even said, based on the breadth of the verse, that it 
was hoped for what is related to the subject of intercession, so the verse did not specify what it gives and what satisfies it.

Delete the sentence:

Examples include the Almighty saying: $p$ If only those who did wrong see that they see torture and that there is no strength for God for all, and that God is strong for torture, for we will find the answer to him, for you will not have the answer. They neglected the truth of God and the right of themselves) and the aesthetics of omission here that the recipient contributes to the production of significance as he goes into interpretation every doctrine, and if the answer was mentioned if it was limited so that there is no room for multiple interpretation doctrines by the multiplicity of recipients and their varying capabilities to imagine the types of torment.

Deletion of semantics

It is intended not to mention the usual meaning of use and association from a text for which it was said to be understood without declaring it; It was created to inspire her.

Including what we find in the analogy field when not declaring the similarities and in the waving and the symbol and the exposure and the indication when the indication is indicated

The first example: The Almighty saying: $p$ He created a person from a clay like pottery .

And also in the words of the poet:

As if the bright sun is a religion that has been hit by the iron barriers

Ibn al-Mu'taz likened the sun to a nearby dinar with a dungeon, and did not mention the similarities of yellowing and sparkling.

And the like in the verse: $p$ and those who disbelieve their mirage Bakaah calculated by the thirsty water even if it came to him did not find anything and found God has The death of his account of God fast account* or Kzlmat in a sea ing covered by waves above it waves from above clouds of darkness on each other if his hand was He hardly sees it, and whoever does not make God a light for him, then he has no light.

As for the second example, in the Almighty saying

poulma mentioned water owes it found a nation of people are watered and found besides them two women Tdhudan said what Khtabkma saying do we water until a Alraae and our father is an old man * is feeling for them and then took to the shade said, I am the Lord revealed to the best of a poor * suddenness one walk timidly She said that my father invites you to reward you for the reward given to you

We observe in the supplication of Moses, peace be upon him, by saying: "Lord, when I was brought to me from poor and good, he indicated his need for shelter and provision, and the text revealed that God had given him the premises of what he needed, so he said: Lord, if not," And also revealed the promise of giving to what is lacking, through the coming of the two of them shyly, and revealed that their father is a great elder who needs a certain.

Selection:

He is with the people of the language ((connected to what defines the meaning)) and when the grammatical ((remove confusion, that is, to inform or mention a word that has faces, then the addressee hesitates in it. Attention is taken to what is meant by stipulating one of its possibilities to show the purpose)) The absolute and its definition, among the interpreters and ((what does not indicate a common one in its gender)) among the fundamentalists.

As for the rhetoric, it is what confines its meaning to something that restricts it and puts it in the rule of a kind with its head. Adverb of the place as: I was beaten in front of you or the object, or the effect for its sake, or discrimination, or condition, and others .

Therefore, the definition is in two parts

The first: diagnostic identification or the so-called (limited by situation); It is that a person is called a name so that if the name is mentioned it is known that the named person was diagnosed and this type of identification is represented by the names of flags, as we called an individual in the name of (Zaid) so we would have restricted him with this name, and distinguished him without him from individuals who carry names different from his name

Among that (knowledge):

It is a name that denotes a specific distinction from other individuals or groups participating in it in the common general traits, such as Zaid knowing for a particular person, and these are a name that is referred to as a specific group, and the grammarians mentioned that knowledge is seven sections, they said: and arranging them according to customary as follows:

The first: the pronoun, such as: I - you - you - he - she - are ... 
The second: science, such as: Zaid - Abi Bakr - Badr Al-Din "and what is added to a pronoun like: my hand - his head - your pen.

Third: the name of the sign, such as: this - this - these.

Fourth: the name of the conductor, such as: who came to me.

Fifth: A sweetener, like: the man - the woman - the believer - the men - the women - the believers.

Sixth: Added to the non-conscience of previous knowledge, such as: "Said's wife - this boy - the pen that visited me in the morning - the book of the man."

VII: The intended nonsense in the call, such as: "0 man" she addresses a specific man .

Examples of what is entrusted to one's own mind include:

5 When he called her, Yamousi, * I am your Lord, and I will exalt you, and that you are in the fold of the holy valley 圆.

As no mention of the word (valley) preceded, but previously knowledge of it, it is entrusted with a mind, for the blame defined for it is for the covenant (the scientific covenant).

Time:

Examples include the Almighty saying: $p$ And if his shirt was made from a seedlings, then I lied, and it is from the truthful 0 . We find glory to him, he has determined the news (cod) for the past time that he benefited (was) to indicate that this matter has happened in the past time Hearer that this matter is happening in the past tense, so the identification has benefited, indicating that the matter happened in the past tense, and that the speaker wants to judge the argument based on what happened in the past tense, to clear one of them and condemn the other.

It also includes his saying: "How can we speak to those who were in the cradle boy" .

The second: The determinant (appointed by the syntax): It is a widening with a conscientious restriction whose meaning is limited to a range and prevents from being common in its gender, which was achieved by not deleting the restriction i.e. mentioning all what is meant by informing about the elements of the sentence in the Arabic tongue because its mention is evidence of the will of the media In it, it corresponds to the deletion in amplitude and includes the non-deletion of the word, sentence and significance as follows

- Do not delete the effect

Among him in the Almighty's saying: "God erases usury and raises alms." (So (usury) and (alms) are specified in the verse. God deserves his debt to the usurer, if he increases his wealth ... and develops alms and increases them by making money for himself in the urgent for the charitable and the reward for it and the reward in the term)) The specific ones exclusively the meaning of the two things they signed, and prevented from spreading the right and the gratitude of God Almighty. The dhikr is not limited to the object of it, but rather the determination is with the object in it and the object with or for it, in addition to the object with absolute effect.

- Do not delete a sentence

And from it in the Almighty saying: $p$ And the land was considered lifeless, so if we descend upon it the water is shaken, raised, and raised from every spouse with joy.

Mention the indication

Examples include what is mentioned in the similarities towards the poet's saying:

How many faces, such as day, are bright for souls like night in darkness?

And from it also in the supplementary redundancy as a precaution towards the Almighty saying p And whoever works of righteous men, male or female, who is a believer, then those who enter the paradise and do not remain (it is not).

Moreover it is restricted

Specify with (condition)

And from him the Almighty said: "And whoever wrongs you, we will inflict a great torment on it." (Punishment in the noble verse came bound by the condition because it was caused by it. The punishment (punishment) is determined by the condition (injustice),

Identification with dependencies (attribute, affirmation, and allowance):

Examples of identifying attributes in the Noble Qur'an are the Almighty saying: p May God bring us out of this unjust village and its people $a$ and in it we find that the reason for leaving is (the injustice of the people of the village); So (adjective) came and restricted the village and limited it to no other.

Among the Qur'anic examples of identification with assertion, the Almighty said: $p$ And what he knows about the day of religion, then what he knows about the day of religion, he was restricted in the noble verse by 
verbal assertion, and this restriction benefited in the sense of intimidation. And its greatness is in the same believers , as the affirmation gave affirmation a new meaning that could not be achieved if it were not.

One example of the Qur'an specifically allowance verse: $p$ Taking Nginakm from Pharaoh Iswmunkm suffering poor slaying your sons and sparing your women 0 The word (torment) in the verse absolute do not know the torment that was Pharaoh Asultouna on the people of Moses (p) type, so His glory came with the restriction (the allowance) to explain the thumb of the type of torment, which is a substitute for both and ((bad) the name of the total torment of pests and disease)) so the specificity of this was clear that this torment is the slaughter of children and the shame of women.

Specify with (sympathetic symmetry)

Among the Qur'an examples of this is the Almighty saying: "So they asked Moses greater than that, so they said: Show us God, speaking openly." Then the thunderbolt took them with an oppression, then they were unjust.

- Specific with (the case): One of his examples is the Almighty saying: $p$ And we said: 0 man, you live, and your spouse married paradise, and both of them are rituals, where you like it and do not reveal this thing. Glory be to him in Surat Al-Baqara using paradise with the word (Raghdah).

Specify with (highlight)

And among them is the Almighty saying: $ه$ Say: Do we tell you about the two losers? .

Specify with (burners):

And from it in the Almighty saying: $p$ If your staff says that I am innocent of what you do then he has determined innocence with the limit of affirmation (that); To demonstrate that the Messenger (may God's prayers and peace be upon him and his family) will never support them because he is innocent of them.

Specify with (neighbor and cyber)

The Almighty said p Say: My Lord extends the sustenance of those who want and worship His servants .

This verse was limited to two terms (from his servants) and (for him), to indicate that the livelihood that will be left behind for him if he spends, is for his righteous servants in particular, so he does not spend from the worship of the righteous and those who believe in him Almighty, and the Almighty does not leave the best for them except for the hypocrites. In spending.

Select with (add)

And he says: $p$ and made them imams dedicate about us and inspired them to do good deeds and prayer, and pay Zakat and they were us Abiding In verse restriction for (verb), and (established), and (paying), though not these limits added to these vocalizations have remained wordy Opaque meaning.

Specify with (chapter pronoun):

And from him, the Almighty said: "Those who disbelieve will not be rich from their money or their children from God, and nothing is from them. And those of them are the fuel of the fire." (He said) Rather, Liddal determined that those are the same fuel, that is, "they are the firewood that leads fire to their bodies."

Moreover, we find that the extent and specificity were defined in the modern stage by the term (open text and closed text) as a matter of paradox, and this was at the hands of Italian Umberto Eco in writing (open work) in 1962

By "open text", that is the text of the definite source, the specified determinant, and the definite meaning, but the definition of meaning does not stop the group of interpretations that follow it, and therefore it was said (open text).

As for (closed text), it is that text that is cloudy and significant, and despite that, it is only possible for one interpretation, which is clearly observed in legal texts, scientific, and at the literary level we note it in police texts and related spy narrations.

(Eko) pointed out the importance of (qualifying the recipient), which is what some authors do when they present their creativity, as they work to surround the recipient with capabilities that help him receive the text, and qualify him to follow his products, which are qualitative and quantitative capabilities, social and cultural, proposed by the recipient, while the closed text It was related to the texts of the specified endings, and if some critics saw that there is a dearth of such texts, so that they are tightly closed at a specific end, and they consider these ends as a temporary closure, because each end is valid to be a new beginning.

As for Klofsky, he deals with building the story, and distinguishes between two forms:

The first form: We can call it (the horizontal form), which is the predominant form of this literary genre, and in fact it belongs (to the open form), where the narration runs horizontally through the symmetric behavior of the person, and during the succession of events. 
The other form: It can be considered (closed form), because it depends on circularity, even if it contains some contradiction, where the beginning is the end, as if the text begins with a prophecy, or a prediction, achieved in the end despite the efforts made by the people to extract from this prophecy, or This speculation .

Todrov contrasts these concepts with something of a violation, as he makes (the closure) from the supplies of the creative text only, while he makes (the opening) of the text of criticism, because the text of criticism has no end, because the critics follow, and each of them reads, and each of them has his views and analyzes .

In defining the concepts of openness and closure, Barthes uses similar erotica nodes, since the closed text equals a relationship confined in itself, while the open text equals a relationship that extends from the verb to its product, which is renewed with its renewal.

One of his examples is the poet's words

If I had known that the end of your reign ... on the day of departure I did what I did not do.

The point of subscribing to this is that the listener does not know anything that indicates his actions in his saying: "I did what I did not do." He wanted to weep if they left, or wander on his face from the grief that befell him, or follow them if they walked, or prevent them from going on with the intention of leaving, or take something from them that reminds them of him, or pay them something that they remember him with, or otherwise, which he may do A lover at a separation loved him, but he did not build

For its purpose; I need the listener to ask him what he wanted to do when they left . Accordingly, amplitude and specificity are two words that are called to judge its context, either by widening; Being not specific to a specific domain or specifically, To bind him to utter interest, allocate his breadth.

\section{References}

1. Rulings in the Rulings of the Rulings: Saif Al-Din Abu Al-Hassan Ali Bin Abi Ali Bin Muhammad Al-Amadi (d. 631 AH), Matt Al-Maaref - Egypt, 1332 AH - 1914 CE.

2. The secrets of rhetoric: Abu Bakr Abd al-Qaher bin Abd al-Rahman bin Muhammad al-Jarjani (Tel: 471 $\mathrm{AH})$, read and commented on by: Mahmoud Muhammad Shakir, Al Madani Press in Cairo, Dar Al Madani, Jeddah.

3. The Equity (by the margin of scouting): Ahmed Ibn al-Munir al-Iskandari, arranged, seized, and authenticated by Mustafa Husayn Ahmad, Matt al-Istikama - Cairo, 2nd edition, 1373 AH - 1953 CE.

4. The proof in the interpretation of the Qur'an: Mr. Hashem Al-Husseini Al-Bahrani: (d. 1107 AH), Mission Foundation - Tehran.

5. The Arabic Rhetoric has its foundations, sciences and arts: for the Arabic Rhetoric: Abd al-Rahman bin Hassan Habbneh, the Damascene Field (T: 1425 AH), Dar Al-Qalam, Damascus, Dar Al-Shamiya, Beirut, I 1,1416 AH - 1996 AD.

6. Explanation in the Sciences of Meanings, Budaiya and Al-Bayan: Sharaf Al-Din Hussain bin Muhammad Al-Tibi, investigation and presentation: Dr. Hadi Atiya Matar Al-Hilali, Matt World of Books - Arab Renaissance Library, 1st edition, 1407-1987 AD.

7. Explanation in the interpretation of the Qur'an: Abu Ja 'far Muhammad ibn al-Hasan ibn Ali al-Tusi (d. 460 $\mathrm{AH})$, investigation: Ahmad Habib Qasir al-Amili, Qom Press - Islamic Information Library, 1st edition, $1379 \mathrm{AH}$.

8. Interpretation of Libra: Mr. Muhammad Hussain al-Tabatabaei (d. $1402 \mathrm{AH}$ ), Tehran Press - Islamic Books House, 2nd edition, Dr.

9. Collector of the provisions of the Qur'an known as (the interpretation of Al-Qurtubi): Muhammad bin Ahmad bin Abi Bakr Al-Qurtubi (d. 671 AH), investigation: Ahmed Abdel-Alim Al-Bardouni, Dar Al-Shaab Press - Cairo, 2nd edition, $1372 \mathrm{AH}$.

10. The Precious Essence: Mr. Abdullah Shubbar (d. 1242 AH), Kuwait Press - Al Alfain Bookshop, 1st Edition, $1407 \mathrm{AH}$.

11. The properties of structures: An analytical study of meanings of issues: Muhammad Muhammad Abu Musa, Wahba Library for Publishing and Distribution, 7th edition.

12. Studies in the fundamentals of interpretation of the Qur'an, d. Abdul Hamid: Mohsen, Matt Al-Watan AlArabi - Baghdad, 1979 AD - 1980 AD.

13. A study of psychology: Roland Barth, translation, Ben Abd El-Aali, Toubkal - 1986.

14. The temporal significance in the Arabic sentence: Dr. Ali Jaber Al-Mansouri: The temporal significance in the Arabic sentence, University Press - Baghdad, 1st edition, 1984 AD

15. Evidence of miracles: Abu Bakr Abd al-Qaher bin Abd al-Rahman bin Muhammad al-Jarjani (d. $471 \mathrm{AH}$ ), investigation: d. Muhammad Al-Tingi, Mati Dar Al-Kitab Al-Arabi, Beirut - Lebanon, 1st edition, 1995. 
16. Two letters in the language: Abu al-Hasan Ali bin Isa bin Ali al-Rammani (d. $388 \mathrm{AH}$ ), by: Ibrahim AlSamarrai, Dar Al-Fikr Press, 1st edition, 1984 AD.

17. Explanation of Summarizing the Key, Ahmed bin Ali Bahaa El-Din El-Sobky, investigation: Abdel Hamid Hindawi, The Modern Library for Printing and Publishing, Byron - Lebanon, first edition 1423.

18. Explanation of the poetry of al-Mutanabbi: Ibrahim bin Muhammad bin Zakaria Al-Zuhri, from Bani Saad bin Abi Waqas, Abu al-Qasim Ibn al-Afili (died: $441 \mathrm{AH}$ ), study and investigation: Dr. Mustafa Alayyan, AlRisala Foundation, 1st edition, Beirut - Lebanon 1412 AH - 1992 AD

19. Explanation of the joint: Mowaffaq al-Din Yaish bin Ali bin Yaish (d. 643 AH), World of Books Press, Beirut - Lebanon, d.

1. 20.

20. Al-Sahbi in Fiqh of the Language: Abu Al-Hussein Ahmad Ibn Faris (d. 395 AH), investigation: Mustafa AlShuwaimi, Badran Institution for Printing and Publishing, Beirut - Lebanon, 1382 AH -1963 AD.

21. The two industries: Abu Hilal al-Hassan bin Abdullah bin bin Mahran al-Askari (d. 395 AH), investigation: Ali Muhammad al-Bajawi and Muhammad Abu al-Fadl Ibrahim, racist library - Beirut - 1419 AH.

22. Arabic grammar, criticism and guidance: Dr. Mahdi Makhzoumi: Matt Al-Raed Al-Arabi, Beirut - Lebanon, 2nd edition, 1406AH -1986AD.

23. Al-Bayan Complex: Amin Al-Din Abu Ali Al-Fadl Bin Al-Hassan Al-Tabarsi (d. 548 AH), Dar Al-Ahyaa Arab Heritage Press, Beirut - Lebanon, 1379 AH, 1/390.

24. Keys to the Origins: Mr. Muhammad Husayn al-Tabatabai (d. 1402 AH), Tehran Press - Dar al-Kitab alIslamiyyah, 3rd edition, $1397 \mathrm{AH}$.

25. Miftah Al-Uloom: Abu Yaqoub Yusef bin Abi Bakr Muhammad bin Ali Al-Sakaki (d. 626 AH), Scientific Advancement Press - Egypt, Dr. T.

26. Criticism of criticism: Todorov, translation: Sami Suwaidan, Arab Perspectives, Baghdad - 1986. 